\title{
Transport of ferric-aerobactin into the periplasm and cytoplasm of Escherichia coli K12: role of envelope-associated proteins and effect of endogenous siderophores
}

\author{
Karl G. Wooldridge, Julie A. Morrissey and Peter H. Williams* \\ Department of Genetics, University of Leicester, Leicester LE1 7RH, UK
}

(Received 6 June 1991; revised 8 October 1991; accepted 22 November 1991)

\begin{abstract}
Purified $\left[{ }^{14} \mathrm{C}\right.$ aerobactin, supplied exogenously to non-growing bacteria, was translocated via the periplasm into the cytoplasm of Escherichia coli K12 strains expressing the aerobactin receptor protein IutA. No significant uptake was observed into either compartment of strains lacking the iut $A$ gene or specifically defective in tonB. Uptake into both compartments was markedly reduced, but not abolished, in an exb mutant. Accumulation of $\left[{ }^{14} \mathrm{Claerobactin}\right.$ in the periplasm of $f h u D, f h u B$ or $f h u C$ mutant strains was not significantly lower than in the wildtype strain, but entry into the cytoplasm was greatly reduced in all cases. Uptake of aerobactin by strains wild-type for all transport functions occurred most efficiently in strains either lacking or specifically defective in the genetic determinants for aerobactin biosynthesis; significantly lower levels of exogenous ${ }^{14} \mathrm{C}$-labelled siderophore were observed in both compartments of strains producing aerobactin. Aerobactin-mediated ${ }^{59} \mathrm{Fe}$ uptake, however, was not inhibited by the presence of endogenous aerobactin. Endogenous enterochelin did not affect aerobactin uptake.
\end{abstract}

\section{Introduction}

Siderophore-mediated uptake of iron by Escherichia coli is initiated by binding of ferric-siderophore complexes to cognate outer-membrane receptor proteins (Braun \& Hantke, 1981; Neilands, 1982). Transport of iron into the periplasmic space then requires the activity of the cytoplasmic membrane protein TonB, which is itself stabilized by ExbB, one of the products of the exb locus (Fischer et al., 1989; Neilands, 1982). Subsequent passage of iron through the periplasm and across the cytoplasmic membrane requires the participation of several gene products which resemble periplasmic transport mechanisms described for some nutrients (Ames, 1986). These systems comprise a hydrophilic protein located in the periplasm, one or two very hydrophobic proteins in the cytoplasmic membrane, and a relatively hydrophilic protein, which is nonetheless also associated with the cytoplasmic membrane, containing regions of extensive homology with ATP-binding proteins. In E. coli, specific systems of this general type are involved in the transport of iron by enterochelin (Ozenberger et al., 1987), citrate (Staudenmaier et al., 1989), and hydroxamate siderophores (Burkhardt \& Braun, 1987; Köster \& Braun, 1989).

\footnotetext{
* Author for correspondence. Tel. (0533) 523436; fax (0533) 523489.
}

Aerobactin-mediated uptake of iron into E. coli cells requires the specific outer-membrane receptor protein IutA (Bindereif et al., 1982; Grewal et al., 1982) for initial binding of the ferric siderophore complex, and the common inner membrane protein TonB (and therefore presumably its functionally associated protein ExbB) for release of iron into the periplasm (Williams, 1979). Analysis of mutants (Braun et al., 1982, 1983; Hantke, 1983), and characterization and localization of proteins (Fecker \& Braun, 1983; Köster \& Braun, 1989), suggest that the products of the $f h u B, f h u C$ and $f h u D$ genes form a common periplasmic binding system for uptake of iron via various hydroxamate siderophores, including aerobactin. FhuD is located in the periplasm, while the hydrophobic protein FhuB and the hydrophilic putative ATP-binding protein FhuC are located in the cytoplasmic membrane and are thought to comprise a cytoplasmic membrane permease complex. However, there are no reports of direct measurements of the uptake of any siderophore into well-defined cellular compartments of $E$. coli, nor physical confirmation of the assumed role of periplasmic binding protein systems in the translocation of siderophores to the cytoplasm. Indeed similar genetic evidence exists for the citrate-mediated ironuptake system of $E$. coli (Frost \& Rosenberg, 1973; Staudenmaier et al., 1989; Wagegg \& Braun, 1981), and 
yet citrate appears not to be transported across the cytoplasmic membrane (Hussein et al., 1981).

Previously a sensitive binding assay for IutA activity involving radiolabelled aerobactin has been described (Roberts et al., 1989). In this paper, the subsequent subcellular localization of receptor-bound aerobactin in wild-type $E$. coli and in mutants lacking each of the necessary envelope-associated functions is reported. Furthermore, the rate of uptake of exogenous aerobactin and of exogenous ferric iron was studied in the presence and absence of endogenous aerobactin.

\section{Methods}

Bacterial strains and plasmids. Characteristics of all strains and plasmids used in this study are described in Table 1. Recombinant plasmid pABN1 contains the entire iron-regulated aerobactin operon of the prototype ColV plasmid ColV-K30, cloned in the vector $\mathrm{pPlac}$ (Bindereif \& Neilands, 1983). Plasmid pLG141 is a subclone of pABN1 carrying the receptor gene iut $A$, but lacking most of the siderophore biosynthesis (iuc) genes, cloned in the vector pACYC184 (Carbonetti \& Williams, 1984); only polypeptides corresponding to the iutA, iucD and cat genes are expressed in minicells harbouring this plasmid. Plasmid ColV-K30iuc was isolated after $N$-methyl- $N^{\prime}$-nitro- $N$-nitrosoguanidine mutagenesis of a strain harbouring plasmid ColV-K30 (Williams \& Warner, 1980). Plasmid pFB102 contains a PstI-EcoRI fragment of $E$. coli chromosomal DNA that includes the entire fhu region containing a Tn5 insertion in $f h u D$; the fragment is cloned into the ampicillinresistance gene of pBR322 (Fecker \& Braun, 1983). Plasmid pBR322 was introduced into plasmid-bearing strains as a source of periplasmic $\beta$-lactamase (Sutcliffe, 1979).

Media and growth conditions. Bacteria were grown either in nutrient broth (Oxoid no. 2) or in M9 minimal salts medium (Roberts et al., 1963) supplemented with $0.2 \%$ glucose, $0.5 \%$ Casamino acids and $20 \mu \mathrm{g}$ L-tryptophan $\mathrm{ml}^{-1}$, and containing $200 \mu \mathrm{M}-2,2$ '-dipyridyl to induce iron-regulated genes. Ampicillin $\left(100 \mu \mathrm{g} \mathrm{ml}^{-1}\right)$ was included in media for the growth of strains carrying plasmids pABN1 and/or pBR322; tetracycline $\left(15 \mu \mathrm{g} \mathrm{ml}^{-1}\right)$ was added to maintain plasmid $\mathrm{pFB} 102$ in strain LF940. Chloramphenicol $\left(20 \mu \mathrm{g} \mathrm{m}^{-1}\right)$ was added to media for growth of strains harbouring pLG141. Cultures were grown aerobically with vigorous agitation at $37^{\circ} \mathrm{C}$.

Preparation of $\left[{ }^{14} \mathrm{C}\right]$ aerobactin. ${ }^{14} \mathrm{C}$-labelled aerobactin was purified from culture supernatants of Aerobacter aerogenes (Klebsiella pneumoniae) strain 62-I incubated at $37^{\circ} \mathrm{C}$ for $4 \mathrm{~h}$ in $10 \mathrm{ml} \mathrm{M9}$ salts medium containing $185 \mathrm{kBq}\left[{ }^{14} \mathrm{C}\right]$ lysine (specific activity $11.99 \mathrm{GBq} \mathrm{mmol}{ }^{-1}$, Amersham). After removal of cells by centrifugation, culture fluid was lyophilized, redissolved in $0.5 \mathrm{ml}$ distilled water and subjected to ascending chromatography on Whatman 3MM paper with a butanol/acetic acid/water (12:3:5, by vol.) solvent system. Labelled products were located by autoradiography, and material of $R_{F}=0.53$ (Gibson \& Magrath, 1969) was eluted in $1 \mathrm{ml}$ distilled water. Aerobactin concentrations were determined from the molar absorption coefficient for ferric aerobactin as reported by Harris et al. (1979).

Preparation of $\left[{ }^{59} \mathrm{Fe} /{ }^{14} \mathrm{C}\right]$ aerobactin. $\left[{ }^{14} \mathrm{C}\right]$ Aerobactin prepared as above was dissolved in $1 \mathrm{mM}$-EDTA before chromatography, and labelled material migrating with $\boldsymbol{R}_{F}=\mathbf{0 . 3}$ (apo-aerobactin) was eluted in $400 \mu \mathrm{l}$ distilled water. Siderophore concentrations were determined as described above (Harris et al., 1979). To $400 \mu \mathrm{l}(313 \mathrm{nmol}$ at $147 \mathrm{MBq} \mathrm{mmol}^{-1}$ ) of this were added $40 \mu 11 \mathrm{M}$-Tris/ $\mathrm{HCl}$ (pH 7.6), $4 \mu \mathrm{l}$ $20 \mathrm{~mm}$-2,2'-dipyridyl, $3.7 \mu{ }^{59} \mathrm{Fe}\left(3.45 \mathrm{nmol} ; 46 \mathrm{kBq}\right.$, as $\mathrm{Fe}$ (II) $\mathrm{SO}_{4}$ in $0.05 \mathrm{M}-\mathrm{H}_{2} \mathrm{SO}_{4}$, Dupont de Nemours, and $31 \mu \mathrm{l} 10 \mathrm{~mm}-\mathrm{FeCl}_{3}$. The mixture was incubated at room temperature for $30 \mathrm{~min}$ before use to allow the formation of $\left[{ }^{59} \mathrm{Fe} /{ }^{14} \mathrm{C}\right]$ aerobactin complex.

Cell fractionation. After incubation of bacterial suspensions with $\left[{ }^{14} \mathrm{C}\right]$ aerobactin or $\left[{ }^{59} \mathrm{Fe} /{ }^{14} \mathrm{C}\right]$ aerobactin, cells were separated into periplasmic and cytoplasmic fractions by a modification of the cold osmotic shock method of Nossal \& Heppel (1966). Inner and outer membranes were separated by differential solubility in Triton X-100 (Schnaitman, 1971). Briefly, bacteria from $1 \mathrm{ml}$ reaction mixtures were washed thoroughly in $10 \mathrm{mM}$-Tris/ $\mathrm{HCl}$ (pH 7.5), $10 \mathrm{~mm}$-EDTA containing $25 \%(\mathrm{w} / \mathrm{v})$ sucrose, resuspended in $0.4 \mathrm{ml}$ ice-cold water, and incubated on ice for $10 \mathrm{~min}$. Cells were recovered by centrifugation.

Table 1. Bacterial strains and plasmids

\begin{tabular}{|c|c|c|}
\hline Strain/plasmid & Relevant properties & Reference \\
\hline \multicolumn{3}{|l|}{ Bacteria } \\
\hline $\begin{array}{l}\text { E. colt K12 } \\
\mathrm{W} 3110\end{array}$ & Wild-type & E. coli $\mathrm{K} 12$ \\
\hline W3110-6 & As W3110 but $e x b$ & $\begin{array}{l}\text { Bachmann (1972) } \\
\text { Fischer et al. (1989) }\end{array}$ \\
\hline AN 1937 & ara entA lac leu mtl proC rpsL supE thi fhuA $x y l$ & Williams (1979) \\
\hline LG1316 & As AN1937 but tonB & Williams (1979) \\
\hline LF940 & recA hsdM hsdR supE lac $Y$ leu thi pro aro fhuB fhuD & Fecker \& Braun (1983) \\
\hline LF947 & recA $\min A \min B$ lacY $x y l$ thi $m t l$ hsdM hsdR fepA fhuC12 & Fecker \& Braun (1983) \\
\hline BU736 & aroB cir tsx malT thi fhuB ColV-K229 & Braun et al. (1982) \\
\hline LG1706 & As BU736 but cured of plasmid ColV-K229 & This study \\
\hline \multicolumn{3}{|l|}{$\begin{array}{l}\text { Aerobacter aerogenes } \\
\text { (Klebsiella pneumoniae) }\end{array}$} \\
\hline $62-I$ & Aerobactin producer & Gibson \& Magrath (1969) \\
\hline \multicolumn{3}{|l|}{ Plasmids } \\
\hline ColV-K30 & $\mathrm{IutA}^{+} \mathrm{Iuc}^{+} \mathrm{Cva}^{+}$ & Williams (1979) \\
\hline ColV-K30iuc & $\mathrm{IutA}^{+} \mathrm{Cva}^{+} i u c$ & Williams \& Warner (1980) \\
\hline pABN1 & IutA $\mathrm{Auc}^{+} \mathrm{Bla}^{+}\left(\mathrm{Ap}^{\mathrm{R}}\right)$ & Bindereif \& Neilands (1983) \\
\hline pLG141 & IutA ${ }^{+} \mathrm{Cat}^{+}\left(\mathrm{Cm}^{\mathrm{R}}\right)$ & Carbonetti \& Williams (1984) \\
\hline pBR322 & $\mathrm{Bla}^{+}$ & Sutcliffe (1979) \\
\hline $\mathrm{pFB} 102$ & fhuB fhuC fhuD:: Tn 5 & Fecker \& Braun (1983) \\
\hline
\end{tabular}


Table 2. Uptake of $\left[{ }^{14} \mathrm{C}\right]$ aerobactin into E. coli $\mathrm{K} 12$ strains lacking specific gene products involved in aerobactin uptake

\begin{tabular}{|c|c|c|c|c|c|}
\hline \multirow[b]{2}{*}{ Strain } & \multirow[b]{2}{*}{$\begin{array}{c}\text { Relevant } \\
\text { characteristics }\end{array}$} & \multicolumn{4}{|c|}{$\left[{ }^{14} \mathrm{C}\right]$ Aerobactin uptake $\left[\mathrm{pmol}(\mathrm{mg} \text { protein })^{-1}\right]^{*}$} \\
\hline & & Periplasm & Cytoplasm & $\begin{array}{c}\text { Inner } \\
\text { membrane }\end{array}$ & $\begin{array}{c}\text { Outer } \\
\text { membrane }\end{array}$ \\
\hline W3110(pLG141) & Wild-type & $25.4(60.7)$ & $15 \cdot 3(36 \cdot 6)$ & $0.5 \quad(1 \cdot 2)$ & $0.6 \quad(1.4)$ \\
\hline W3110 & Iut $A^{-}$ & $2.33(37.4)$ & $1.3(20.9)$ & $1.7(27 \cdot 3)$ & $0.9(14.4)$ \\
\hline LG1316(pLG141) & $\operatorname{ton} B$ & $3.22(46 \cdot 5)$ & $1 \cdot 1(15.9)$ & $1.7(24.6)$ & $0.9(13.0)$ \\
\hline W3110-6(pLG141) & $e x b$ & $6.76(45.5)$ & $5.7(38.4)$ & $1.6(10.8)$ & $0.8(5.4)$ \\
\hline LF940(pFB102, pLG141) & fhuD & $25 \cdot 1 \quad(93 \cdot 3)$ & $0.9(3.3)$ & $0.3(1 \cdot 1)$ & $0.6 \quad(2.2)$ \\
\hline LG1706(pLG141) & fhuB & $17.8 \quad(75 \cdot 7)$ & $4.0(17.0)$ & $0.4 \quad(1.7)$ & $1.3 \quad(5.5)$ \\
\hline LF947(pLG141) & fhuC & $21.8 \quad(75 \cdot 2)$ & $3.7(12 \cdot 8)$ & $1.6 \quad(5.5)$ & $1.9 \quad(6.6)$ \\
\hline AN1937(pLG141) & entA & $33 \cdot 3 \quad(61 \cdot 2)$ & $20.0(36.8)$ & $0.5 \quad(0.9)$ & $0.6 \quad(1 \cdot 1)$ \\
\hline W3110(pABN1) & Iuc $^{+}$ & $11.6 \quad(77.9)$ & $3 \cdot 3(22 \cdot 1)$ & - & - \\
\hline
\end{tabular}

-, Not determined.

* Values in parentheses are percentages of total cell-associated label in each compartment.

Supernatant (periplasmic) fractions were removed and spheroplast pellets were resuspended in $0.4 \mathrm{ml} 10 \mathrm{mM}-\mathrm{Tris} / \mathrm{HCl}(\mathrm{pH} 7.5)$. Spheroplasts were disrupted by sonication and subjected to ultracentrifugation $(100000 \mathrm{~g}$ for $10 \mathrm{~min}$ ). Supernatant (cytoplasmic) fractions were removed and pellets (membranes) were resuspended in $0.4 \mathrm{ml} 10 \mathrm{mM}$ Tris/ $/ \mathrm{HCl}_{\text {( }}(\mathrm{pH} / 7.5)$ containing $2 \%$. $(\mathrm{v} / \mathrm{v})$ Triton $\mathrm{X}-100$ and incubated at room temperature for $30 \mathrm{~min}$. After ultracentrifugation, supernatant fractions (cytoplasmic membranes) were removed and pellets (Tritoninsoluble outer membranes) were resuspended in $0.4 \mathrm{ml}$ of the same buffer. Radioactivity associated with each fraction was measured after addition of $4 \mathrm{ml}$ Optiphase $X$ scintillation cocktail (Pharmacia) in a Packard Tri-Carb 2000A liquid scintillation analyser. In single-label experiments ${ }^{14} \mathrm{C}$ emissions were measured in a window of 0-156 keV. For measurement of double-labelled cell fractions, ${ }^{59} \mathrm{Fe}$ activity was calculated from emissions measured in a window of $80-2000 \mathrm{keV}$ (accounting for $25 \%$ of total ${ }^{59} \mathrm{Fe}$ emissions), and ${ }^{14} \mathrm{C}$ activity was calculated from the emissions measured in a window of $0-10 \mathrm{keV}$, after subtraction of the ${ }^{59} \mathrm{Fe}$ contribution $\left(12 \%\right.$ of total ${ }^{59} \mathrm{Fe}$ emissions); this accounts for $25 \%$ of ${ }^{14} \mathrm{C}$ emissions.

Enzyme assays of subcellular fractions. To determine the purity of periplasmic and cytoplasmic fractions, enzyme activities characteristic of the two cellular compartments were determined. The periplasmic enzyme $\beta$-lactamase, encoded by the bla gene of pBR322, was assayed by conversion of the chromogenic substrate nitrocefin (Glaxo) to a product quantifiable by absorbance measurements at $482 \mathrm{~nm}$. The cytoplasmic marker was the chromosomally encoded enzyme malate dehydrogenase, assayed by conversion of oxaloacetic acid to a product quantifiable by absorbance measurements at $340 \mathrm{~nm}$. Cytoplasmic fractions routinely contained less than $8 \%$ of total cellular $\beta$-lactamase activity, and periplasmic fractions consistently contained only $3 \%$ of total cellular malate dehydrogenase activity.

\section{Results}

\section{Cellular localization of aerobactin}

Various types of cells carrying plasmid pLG141 and expressing IutA protein constitutively (Carbonetti \& Williams, 1984), were grown overnight in nutrient broth containing $200 \mu \mathrm{M}$-dipyridyl, washed and resuspended in phosphate-buffered saline containing $200 \mu \mathrm{M}$-dipyridyl to an $\mathrm{OD}_{600}$ of $1 .{ }^{14} \mathrm{C}$-labelled aerobactin (approximately $4.5 \mathrm{nmol}$, specific activity $414 \mathrm{MBq} \mathrm{mmol}^{-1}$ ) was added to $1 \mathrm{ml}$ samples of cell suspension and incubated at $37^{\circ} \mathrm{C}$ for $90 \mathrm{~min}$. Uptake of radiolabelled aerobactin into the four cellular fractions of strains with various defined mutations affecting utilization of aerobactin as an iron source was determined as described in Methods (Table 2). Radioactivity associated with membrane fractions of all strains tested was negligible, suggesting only transient association of aerobactin. However, significant levels of radioactivity were observed in both the periplasmic and cytoplasmic fractions of the wild-type strain W3110(pLG141), but not of strain W3110, which lacks the plasmid-encoded iut $A$ gene, nor of the ton $B$ strain LG1316(pLG141). These data confirm the requirement of aerobactin iron transport for IutA and TonB functions (Bindereif et al., 1982; Braun et al., 1982; Williams, 1979). Uptake into both cellular compartments of the exbB strain W3110-6(pLG141) was also markedly reduced compared with W3110(pLG141), but was nonetheless significantly higher than into ton $B$ cells. This is consistent with earlier findings that requirement for exb gene products is less stringent than for TonB in TonB-dependent uptake mechanisms (Fischer et al., 1989).

Accumulation of $\left[{ }^{14} \mathrm{C}\right]$ aerobactin in the periplasmic compartments of the three fhu mutant strains LF940(pFB102, pLG141), LG1706(pLG141) and LF947(pLG141) was similar to that in the periplasm of W3110(pLG141). However, uptake into the cytoplasm of the fhuD mutant LF940(pFB102, pLG141) was negligible, confirming that the periplasmic binding protein FhuD is absolutely required for translocation of aerobactin across the cytoplasmic membrane. By contrast, the $f h u B$ and $f h u C$ strains LG1706 and LF947 harbour- 
ing pLG141 consistently showed low (compared with the wild-type) but significant levels of uptake of aerobactin into the cytoplasmic fraction. It is possible that defects in either of the cytoplasmic membrane functions involved in periplasmic transport of ferric-hydroxamate compounds are partially complemented by equivalent components of other systems. Alternatively, if the mutations do not result in complete absence of gene products, mutant proteins may have residual activity which could account for the observed leakiness. The precise nature of the genetic lesions in these mutants has not been determined.

\section{Effect of endogenous siderophores on aerobactin uptake}

Strain AN1937 is an entA mutant strain that is unable to synthesize enterochelin. A derivative of AN1937 harbouring plasmid pLG141 accumulated levels of radioactive aerobactin in the periplasmic and cytoplasmic fractions similar to those observed for the $\mathrm{Ent}^{+}$ strain W3110(pLG141) (Table 2). Thus, the ability to make enterochelin has no effect on the rate or extent of uptake of aerobactin from the medium. On the other hand, the presence of endogenous aerobactin appears to inhibit markedly the uptake of exogenously supplied aerobactin; strain $\mathrm{W} 3110$ carrying plasmid pABN1, which specifies aerobactin biosynthesis as well as receptor activity (Iuc ${ }^{+} \operatorname{IutA}^{+}$), showed significantly lower levels of $\left[{ }^{14} \mathrm{C}\right] \mathrm{aerobactin}$ in both cellular compartments compared with W3110(pLG141) (Table 2). Similar effects were observed with a strain containing the entire aerobactin plasmid ColV-K30 (data not shown); ${ }^{14} \mathrm{C}$ levels associated with the periplasm and cytoplasm of strain W3110(ColV-K30) were two-thirds and half, respectively, of those observed for the corresponding compartments of strain W3110(pLG141). It should be stressed, however, that these plasmids are not directly comparable. First, the aerobactin operon in plasmids pABN1 and ColV-K30 is iron regulated (Roberts et al. 1986). Second, ColV-K30 has a copy number of one or two per cell, while pLG141 and pABN1 are multicopy plasmids.

To determine whether variations in levels of iutA transcription or gene dosage could account for these observations, the uptake of radiolabelled siderophore into isogenic W3110 strains containing either the prototype aerobactin plasmid ColV-K30, or a mutant derivative ColV-K30iuc (Williams \& Warner, 1980) was compared. Bacteria were grown overnight in minimal medium containing dipyridyl to induce maximal transcription of the aerobactin operon and full expression of the iut $A$ gene in both plasmids. Cells were incubated with $\left[{ }^{14} \mathrm{C}\right]$ aerobactin for $90 \mathrm{~min}$ as described above. The iuc mutant strain consistently accumulated significantly more exogenously supplied aerobactin in both cellular compartments than did the wild-type $\mathrm{Iuc}^{+}$strain $(P<0.025): 15.2 \mathrm{pmol}(\mathrm{mg} \text { protein })^{-1}$ compared with $5.4 \mathrm{pmol}$ ( $\mathrm{mg}$ protein $)^{-1}$ into the periplasm, and $12.6 \mathrm{pmol}(\mathrm{mg} \text { protein })^{-1}$ compared with $5.6 \mathrm{pmol}(\mathrm{mg}$ protein $)^{-1}$ into the cytoplasm. Values obtained for uptake into each compartment are means of readings from three independent experiments and were compared for significance using a test based on the Student- $t$ distribution (Walpole, 1982).

A possible explanation for this difference is that the specific activity of $\left[{ }^{14} \mathrm{C}\right]$ aerobactin was reduced by unlabelled siderophore secreted by producing strains. Since less than $2.5 \%$ of the total radioactivity in a reaction mixture was actually taken up by receptive bacteria, the level of residual radioactivity in the reaction mixture was not measurably altered and buffers recovered after uptake assays could therefore be reused. Incubation buffers used to determine $\left[{ }^{14} \mathrm{C}\right]$ aerobactin uptake by strains W3110(ColV-K30) and W3110(ColV$\mathrm{K} 30$ iuc) were therefore subsequently used to label nutrient-broth-cultured W3110(pLG141) cells over a further $90 \mathrm{~min}$ incubation period. Virtually identical levels of uptake were observed [740 c.p.m. in cells incubated in buffer pre-incubated with W3110(ColVK30) compared with 654 c.p.m. in cells incubated in buffer pre-incubated with W3110(ColV-K30iuc)], indicating that reduced accumulation of radioactivity by the strain carrying ColV-K30 was not due to significant changes in specific activity of external $\left[{ }^{14} \mathrm{C}\right]$ aerobactin. Values for uptake into W3110(pLG141) cells are means of two independent experiments.

\section{The fate of iron taken up as ferric-aerobactin}

To determine whether uptake of iron complexed with aerobactin, like uptake of aerobactin itself, was inhibited by the presence of endogenous siderophore, double label experiments using $\left[{ }^{59} \mathrm{Fe} /{ }^{14} \mathrm{C}\right]$ aerobactin were carried out. Bacteria were grown overnight in nutrient broth containing dipyridyl, washed and resuspended in phosphate-buffered saline containing dipyridyl and $\left[{ }^{59} \mathrm{Fe} /{ }^{14} \mathrm{C}\right]$ aerobactin $(8 \mathrm{mmol}$, specific activity $14 \mathrm{MBq} \mathrm{mmol}{ }^{-1}$ ) to an $\mathrm{OD}_{600}$ of $0 \cdot 1$. At intervals during incubation at $37^{\circ} \mathrm{C}$, duplicate $1 \mathrm{ml}$ aliquots were removed for cell fractionation and determination of ${ }^{59} \mathrm{Fe}$ and $\left[{ }^{14} \mathrm{C}\right]$ aerobactin associated with subcellular compartments (Fig. 1). Accumulation of ${ }^{59} \mathrm{Fe}$ into the cytoplasmic fraction of $\mathrm{W} 3110(\mathrm{pABN} 1)$ cells exceeded that of $\left[{ }^{14} \mathrm{C}\right]$ aerobactin by more than twofold over a $2 \mathrm{~h}$ period, while in the periplasm the reverse was the case (Fig. $1 a$ ). This is consistent with a model in which iron is removed, possibly at the cytoplasmic membrane, and aerobactin is rapidly recycled in aerobactin-producing 


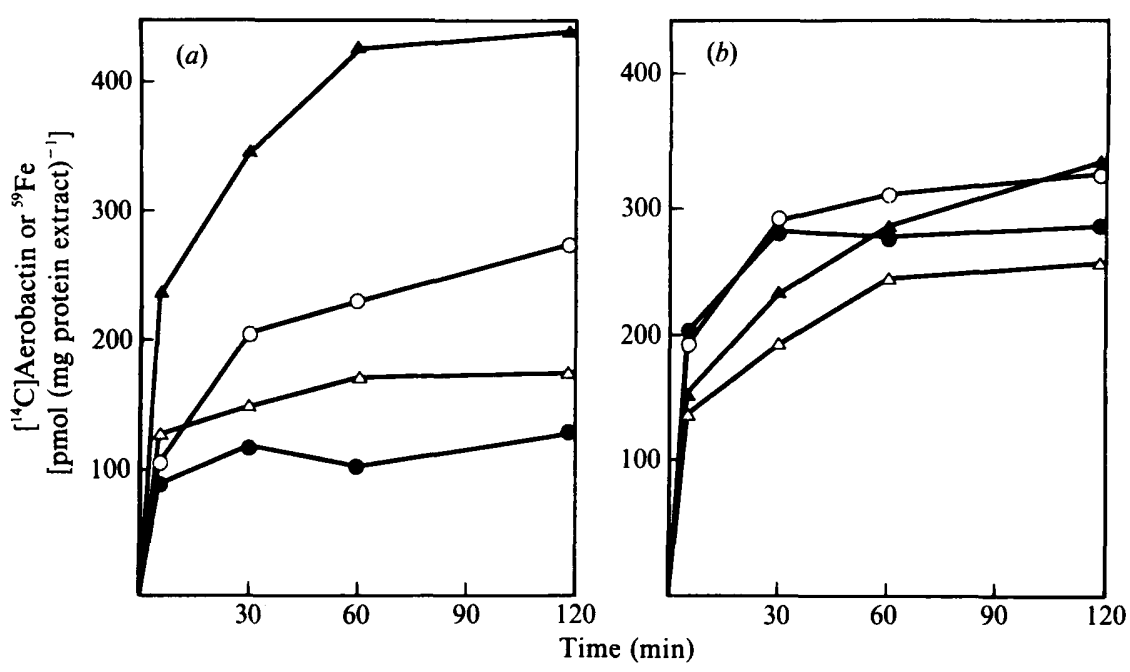

Fig. 1. Uptake of $\left[{ }^{59} \mathrm{Fe} /{ }^{14} \mathrm{C}\right]$ aerobactin by bacteria expressing the aerobactin receptor IutA. (a) The aerobactin-producing strain W3110(pABN1); (b) the aerobactin-deficient strain W3110(pLG141). Accumulation of ${ }^{14} \mathrm{C}$ (open symbols) and ${ }^{59} \mathrm{Fe}$ (filled symbols) activity in the periplasmic $(O, \bullet)$ and cytoplasmic $(\triangle, \Delta)$ fractions was determined at intervals during incubation at $37^{\circ} \mathrm{C}$ as described in Methods.

cells. The siderophore returns via the periplasm to the external medium. By contrast, uptake of aerobactin and iron into the non-aerobactin-producing cells of strain W3110(pLG141) occurred at similar levels into both compartments (Fig. $1 b$ ). These data strongly suggest that ferric-aerobactin enters the cytoplasm as an intact complex. Interestingly, at later time points, when significant levels of exogenously supplied iron may have accumulated, similar patterns of differential uptake of the two labels were observed in these cells also, albeit at a much lower magnitude than with the aerobactinproducing strain. No significant uptake into either compartment of cells of strain W3110 was observed (data not shown), ruling out the possibility that enterochelin (which all these strains are able to make) may be contributing to the observed assimilation of aerobactinbound iron.

\section{Discussion}

The genes whose products make up periplasmic iron transport systems have been identified on the basis of the inability of mutant strains to use a particular siderophore as a sole iron source (Braun et al., 1982, 1983; Hantke, 1983; Ozenberger et al., 1987; Pierce et al., 1983; Pressler et al., 1988; Staudenmaier et al., 1989). In general, constituent proteins were localized by analysis of particular subcellular compartments (Fecker \& Braun, 1983; Köster \& Braun, 1989; Ozenberger et al., 1987; Pressler et al., 1988; Staudenmaier et al., 1989). Despite apparent similarities in genetic and physical organiz- ation, however, the fate of the siderophore-iron complex as it traverses the cell envelope is not necessarily the same in each case. On the one hand, with ferric-dicitrate, iron accumulates in $E$. coli cells but citrate does not, suggesting that the complex is not transported intact into the cytoplasm, but rather that iron is removed within the cell envelope (Hussein et al., 1981). On the other hand, the observation that some siderophores are chemically modified and then excreted after delivering their iron to $E$. coli cells provides indirect evidence for uptake into the cytoplasm. The hydroxamate siderophore ferrichrome, for example, is acetylated (Hartmann \& Braun, 1980). Despite previous observations that acetylase activity could be demonstrated in cell-free membrane preparations (Schneider et al., 1981), it is generally assumed that ferrichrome is modified after transport across the cytoplasmic membrane (Fischer et al., 1989; Köster \& Braun, 1989).

The catechol siderophore enterochelin is hydrolysed by a cytoplasmic esterase, possibly as a pre-requisite for release of iron, the reduction potential of ferricenterochelin at neutral $\mathrm{pH}$ being outside the range of biological reductants (O'Brien et al., 1971). It has also been suggested, however, that the relatively low $\mathrm{pH}$ of the periplasmic compartment may allow reductive removal of iron from enterochelin before passage into the cytoplasm (Ecker et al., 1986). Indeed, in faintly acidic solutions, the siderophore itself tends to reduce ferric iron (Hider, 1984). Further support for the suggestion that cytoplasmic ferric-enterochelin esterase may not in fact be required for removal of iron in vitro comes from the observation that synthetic analogues of enterochelin 
that are not susceptible to hydrolysis are nonetheless biologically active in growth promotion assays (Heidinger et al., 1983). Thus, it is still unclear whether ferric-enterochelin is delivered as an intact complex to the cytoplasm, or if iron is removed by reduction in the periplasm.

Unlike ferrichrome and enterochelin, aerobactin seems not to be modified after assimilation, and may be recycled for subsequent rounds of iron uptake (Braun $e t$ al., 1984). In this paper direct evidence for accumulation of aerobactin in the periplasm and cytoplasm of nongrowing bacteria that do not themselves make aerobactin is provided. In general, higher absolute levels were observed in the periplasm, despite the fact that the volume of this compartment under normal conditions is significantly less than that of the cytoplasm (Stock et al., 1977). This is not surprising, however, since it has been known for some time that siderophore uptake across the outer membrane may be more rapid than across the cytoplasmic membrane (Fecker \& Braun, 1983). The physiological relevance of this observation is confirmed by the behaviour of various mutants unable to grow with aerobactin as an iron source. Thus, iut $A, \operatorname{ton} B$ and $e x b$ mutant strains exhibited significantly reduced levels of uptake of radiolabelled aerobactin into the periplasm. On the other hand, $f h u B, f h u C$ and $f h u D$ mutant cells showed normal accumulation of aerobactin in the periplasm, but were defective in transport of the siderophore into the cytoplasm. Presumably, aerobactin bound to Iut $A$ is released into the periplasm by a TonB(Exb)-dependent mechanism that does not require the periplasmic FhuD protein. FhuD subsequently binds aerobactin in the periplasm and delivers it to the cytoplasmic membrane permease complex FhuBC, which in turn catalyses transport into the cell. This is in contrast to the uptake of maltodextrins, which are taken up by a process of facilitated diffusion via the outermembrane protein LamB (Wandersman et al., 1979). In this case the periplasmic binding protein MalE seems to be required for transport across both outer and cytoplasmic membranes.

Uptake of aerobactin by aerobactin-producing strains was significantly lower than by strains that expressed only the aerobactin receptor gene iutA. A similar observation was previously reported for schizokininmediated iron uptake into the Gram-positive organism Bacillus megaterium (Arceneaux et al., 1973); exogenously supplied ferric-schizokinin remained associated with bacteria in which intracellular siderophore concentrations were low, but was rapidly lost from schizokinin-producing cells. By contrast, however, uptake into the cytoplasm of the iron component of ferric-aerobactin was unaffected by the presence of endogenous siderophore. Preferential accumulation of iron over aerobactin in the cytoplasm might result from rapid re-excretion of siderophore after removal of iron within the cytoplasm. If this were the case a similar effect would be expected in cells that do not produce aerobactin; however, iron and aerobactin accumulate at comparable levels in the cytoplasm of strain W3110(pLG141). Another possibility is that iron is removed from the labelled aerobactin in the periplasm by endogenous aerobactin and delivered to the cytoplasm. Levels of endogenous aerobactin found in the periplasm are not sigificantly greater, however, than the levels of aerobactin taken up, and unless one proposes a very rapid exchange of iron between aerobactin molecules this could not account for the observed reduction of uptake of labelled aerobactin across the cytoplasmic membrane. Kinetic exchange between siderophore molecules has in fact been reported to be extremely slow (Tufano \& Raymond, 1981).

It is therefore proposed that when endogenous aerobactin levels are high some of the receptor-bound exogenous aerobactin is released from the cytoplasmic membrane, perhaps following reduction of ferric iron, or exchange of ferric ions with internal siderophore molecules. The mechanism by which such exchange could occur, however, is not known. Previously it has been proposed that iron supplied to iron-stressed bacteria by aerobactin, unlike that delivered by enterochelin, exists in an intracellular complexed form rather than being released into a cytoplasmic pool, since cells using aerobactin for growth were insensitive to the iron-dependent antibiotic streptonigrin (Williams \& Carbonetti, 1986). One possibility suggested by the data presented here is that aerobactin may have a role in intracellular storage and mobilization of ferric iron within the cytoplasm.

We are grateful to V. Braun for providing strains W3110-6, LF940, LF947, BU736, and plasmid pFB102, and to J. B. Neilands for plasmid pABN1. We thank G. Turnock for help and advice on liquid scintillation analysis. K.G.W. acknowledges receipt of a Medical Research Council Studentship.

\section{References}

Ames, G. F. L. (1986). Bacterial periplasmic transport systems: structure, mechanism, and evolution. Annual Review of Biochemistry 55, 397-425.

Arceneaux, J. E. L., Davis, W. B., Downer, D. N., Haydon, A. H. \& BYERS, B. R. (1973). Fate of labeled hydroxamates during iron transport from hydroxamate-iron chelates. Journal of Bacteriology 115, 919-927.

BachmanN, B. J. (1972). Pedigrees of some mutant strains of Escherichia coli K-12. Bacteriological Reviews 36, 525-557.

BINDEREIF, A. \& NeILANDS, J. B. (1983). Cloning of the aerobactinmediated iron assimilation system of plasmid ColV. Journal of Bacteriology 153, 1111-1113. 
Bindereif, A., Braun, V. \& HantKe, K. (1982). The cloacin receptor of ColV-bearing Escherichia coli is part of the $\mathrm{Fe}^{3+}$-aerobactin transport system. Journal of Bacteriology 150, 142-145.

BrAUN, V. \& HANTKE, K. (1981). Bacterial cell surface receptors. In Organization of Prokaryotic Cell Membranes, vol. II, pp. 1-73. Edited by B. K. Ghosh. Boca Raton, Florida: CRC Press.

BRAUN, V., BURKHARDT, R., SCHNEIDER, R. \& ZimmermanN, L. (1982). Chromosomal genes for ColV plasmid-determined iron(III)-aerobactin transport in Escherichia coli. Journal of Bacteriology 151, 553-559.

Braun, V., Gross, R., Köster, W. \& ZimmermanN, L. (1983). Plasmid and chromosomal mutants in the iron(III)-aerobactin transport system of Escherichia coli. Use of streptonigrin for selection. Molecular and General Genetics 192, 131-139.

Braun, V., Brazel-Faisst, C. \& Schneider, R. (1984). Growth stimulation of Escherichia coli in serum by iron(III) aerobactin. Recycling of aerobactin. FEMS Microbiology Letters 21, 99-103.

BURKHARDT, R. \& BRAUN, V. (1987). Nucleotide sequence of the $f$ huC and $f h u D$ genes involved in iron(III) hydroxamate transport: domains in FhuC homologous to ATP-binding proteins. Molecular and General Genetics 209, 49-55.

Carbonetti, N. H. \& Williams, P. H. (1984). A cluster of five genes specifying the aerobactin iron uptake system of plasmid ColV-K 30. Infection and Immunity 46, 7-12.

EckeR, D. J., Matzanke, B. F. \& Raymond, K. N. (1986). Recognition and transport of ferric enterobactin in Escherichia coli. Journal of Bacteriology.167, 666-673.

FeCKER, L. \& Braun, V. (1983). Cloning and expression of the fhu genes involved in iron(III)-hydroxamate uptake by Escherichia coli. Journal of Bacteriology 156, 1301-1314.

FISCHER, E., GÜNTER, K. \& BRAUN, V. (1989). Involvement of ExbB and TonB in transport across the outer membrane of Escherichia coli: phenotypic complementation of exb mutants by overexpressed ton $B$ and physical stabilization of TonB by ExbB. Journal of Bacteriology 171, 5127-5134.

Frost, G. E. \& Rosenberg, H. (1973). The inducible citrate dependent iron transport system in Escherichia coli K-12. Biochimica et Biophysica Acta 330, 90-101.

Gibson, F. \& MaGrath, D. I. (1969). The isolation and characterization of a hydroxamic acid (aerobactin) formed by Aerobacter aerogenes 62-I. Biochimica et Biophysica Acta 192, 175-184.

Grewal, K. K., Warner, P. J. \& Williams, P. H. (1982). An inducible outer membrane protein involved in aerobactin-mediated iron transport by ColV strains of Escherichia coli. FEBS Letters 140, 27-30.

HANTKE, K. (1983). Identification of an iron uptake system specific for coprogen and rhodotorulic acid in Escherichia coli K12. Molecular and General Genetics 191, 301-306.

Harris, W. R., Carrano, C. J. \& Raymond, K. N. (1979). Coordination chemistry of microbial iron transport compounds. 16. Isolation, characterization, and formation constants of ferric aerobactin. Journal of the American Chemical Society 101, 222-227.

HARTMANN, A. \& BRAUN, V. (1980). Iron transport in Escherichia coli: uptake and modification of ferrichrome. Journal of Bacteriology 143 246-255.

Heidinger, S., Braun, V., Pecoraro, V. L. \& Raymond, K. N. (1983). Iron supply to Escherichia coli by synthetic analogs of enterochelin. Journal of Bacteriology 153, 109-115.

HIDER, R. C. (1984). Siderophore mediated absorption of iron. Structure and Bonding 58, 25-87.

Hussein, S., HantKe, K. \& Braun, V. (1981). Citrate-dependent iron transport system in Escherichia coli K-12. European Journal of Biochemistry 11, 431-437.

KösTER, W. \& BRAUN, V. (1989). Iron-hydroxamate transport into Escherichia coli $\mathrm{K} 12$ : localization of FhuD in the periplasm and of FhuB in the cytoplasmic membrane. Molecular and General Genetics 217, 233-239.

NeILANDS, J. B. (1982). Microbial envelope proteins related to iron. Annual Review of Microbiology 36, 285-309.
Nossal, N. G. \& Heppel, L. A. (1966). The release of enzymes by osmotic shock from Escherichia coli in exponential phase. Journal of Biological Chemistry 241, 3055-3062.

O'Brien, I. G., CoX, G. B. \& Gibson, F. (1971). Enterochelin hydrolysis and iron metabolism in Escherichia coli. Biochimica et Biophysica Acta 23, 537-549.

OZENBERGER, B. A., NAHLIK, M. S. \& McINTOSH, M. A. (1987). Genetic organization of multiple fep genes encoding ferric enterobactin transport functions in Escherichia coli. Journal of Bacteriology 169, 3638-3646.

Pierce, J. R., Pickett, C. L. \& Earhart, C. F. (1983). Two fep genes are required for ferrienterochelin uptake in Escherichia coli $\mathrm{K}-12$. Journal of Bacteriology 155, 330-336.

Pressler, U., Staudenmaler, H., ZimmermanN, L. \& Braun, V. (1988). Genetics of the iron dicitrate transport system of Escherichia coli. Journal of Bacteriology 170, 216-224.

Roberts, M., Leavitt, R. W., Carbonetti, N. H., Ford, S., CoOper, R. A. \& Williams, P. H. (1986). RNA-DNA hybridization analysis of transcription of the plasmid ColV-K30 aerobactin gene cluster. Journal of Bacteriology 167, 467-472.

Roberts, M., Wooldridge, K. G., Gavine, H., Kuswandi, S. I. \& Williams, P. H. (1989). Inhibition of biological activities of the aerobactin receptor protein in rough strains of Escherichia coli by polyclonal antiserum raised against native protein. Journal of General Microbiology 135, 2387-2398.

Roberts, R. B., Abelson, P. H., CoWie, D. B., Bolton, E. T. \& Britten, R. J. (1963). Studies of biosynthesis in Escherichia coli. Publication no. 60, Carnegie Institute of Washington, Washington, DC.

SchNaItMan, C. A. (1971). Solubilization of the cytoplasmic membrane of Escherichia coli by Triton X-100. Journal of Bacteriology 108, 545-552.

SCHNEIDER, R., HARTMANN, A. \& BRAUN, V. (1981). Transport of the iron ionophore ferrichrome in Escherichia coli K-12 and Salmonella typhimurium LT2. FEMS Microbiology Letters 11, 115-119.

Staudenmaier, H., Van Hove, B., Yaraghi, Z. \& Braun, V. (1989). Nucleotide sequences of the fecBCDE genes and locations of the proteins suggest a periplasmic-binding-protein-dependent transport mechanism for iron(III) dicitrate in Escherichia coli. Journal of Bacteriology 171, 2626-2633.

Stock, J. B., Rauch, B. \& Roseman, S. (1977). Periplasmic space in Salmonella typhimurium and Escherichia coli. Journal of Biological Chemistry 252, 7850-7861.

SuTCLIFFE, J. G. (1979). Complete nucleotide sequence of the Escherichia coli plasmid pBR322. Cold Spring Harbor Symposia on Quantitative Biology 43, 77-90.

TUFANO, T. P. \& RAYMOND, K. N. (1981). Coordination chemistry of microbial iron transport compounds. 21. Kinetics and mechanism of iron exchange in hydroxamate siderophore complexes. Journal of the American Chemical Society 103, 6617-6624.

WAGEGG, W. \& Braun, V. (1981). Ferric citrate transport in Escherichia coli requires outer membrane receptor protein FecA. Journal of Bacteriology 145, 156-163.

Wandersman, C., Schwartz, M. \& Ferenci, T. (1979). Escherichia coli mutants impared in maltodextrin transport. Journal of Bacteriology 140, 1-13.

WALPOLE, R. E. (1982). Introduction to Statistics, 3rd edn. New York: Macmillan.

Williams, P. H. (1979). Novel iron uptake system specified by ColV plasmids: an important component in the virulence of invasive strains of Escherichia coli. Infection and Immunity 26, 925-932.

Williams, P. H. \& CarbonetTi, N. H. (1986). Iron, siderophores, and the pursuit of virulence: independence of the aerobactin and enterochelin iron uptake systems in Escherichia coli. Infection and Immunity 51, 942-947.

Williams, P. H. \& Warner, P. J. (1980). ColV plasmid-mediated, colicin V-independent iron uptake system of invasive strains of Escherichia coli. Infection and Immunity 29, 411-416. 